\title{
SPOŁECZNA KONSTRUKCJA NIEPODLEGŁOŚCI KOSOWA
}

\author{
Patrycja Zając \\ I rok studiów III stopnia, Nauki o polityce, \\ Zakład Stosunków Miẹdzynarodowych, Uniwersytet Marii Curie-Skłodowskiej \\ Plac Litewski 3, 20-080 Lublin, patrycja.zajac1@gmail.com
}

\begin{abstract}
Streszczenie. Artykuł stanowi próbę analizy suwerenności Kosowa z zastosowaniem społecznej teorii stosunków międzynarodowych. Przedstawia ewolucję definiowania suwerenności oraz ukazuje konflikt zasady samostanowienia narodów i integralności terytorialnej na przykładzie Kosowa. Prezentuje znaczenie norm i wartości dla funkcjonowania środowiska międzynarodowego. Wskazuje, jaki wpływ odegrały czynniki niematerialne (głównie tożsamość narodowa) na ukształtowanie interesów narodowych, w tym niepodległego państwa. Kultura, historia i mity narodowe mają kluczowe znaczenie dla kreowania zachowań obu stron konfliktu. Artykuł prezentuje główne wyznaczniki suwerenności Kosowa - terytorium, ludność, władzę.
\end{abstract}

Słowa kluczowe: Kosowo, Serbia, Albania, niepodległość, społeczna konstrukcja stosunków międzynarodowych

\section{UWAGI WSTĘPNE}

Niepodległość Kosowa jest nadal kwestią bardzo dyskusyjną. Samodzielność nowego podmiotu w środowisku międzynarodowym jest często podważana i krytykowana. Uzależnienie od pomocy międzynarodowej Unii Europejskiej i Stanów Zjednoczonych kłóci się z obrazem niepodległego państwa. Część podmiotów międzynarodowych akceptuje jego niezależność, ale istnieje grupa państw, która ze względu na własne interesy i bezpieczeństwo nie wyraża chęci uznania nowego podmiotu. Duże znaczenie w zrozumieniu istoty konfliktu ma określenie wpływu kultury i doświadczeń historycznych na jego rozwój. Wymienione czynniki ukształtowały tożsamość obu narodów, co pozwoliło im na artykulację własnych interesów (stworzenie własnego państwa lub zachowanie integralności).

Problemem przedstawionym w niniejszym artykule jest status Kosowa zarówno de iure jak i de facto - na arenie międzynarodowej. Celem pracy jest przede wszystkim analiza niepodległości Kosowa jako społecznej konstrukcji. W artykule weryfikacji poddano dwie hipotezy badawcze. Po pierwsze, spór o Kosowo wynika z konfliktu priorytetu zasad - integralności terytorialnej oraz 
prawa narodów do samostanowienia. Obie normy są pochodną praktyki międzynarodowej i zostały przyjęte przez aktorów struktury. Problem polega na tym, że w momencie, w którym stanowią podstawę dla sprzecznych interesów, mogą prowadzić do konfliktu. Po drugie, sfera niematerialna ma znaczący wpływ na tworzenie społecznej konstrukcji niepodległości. Artykulacja interesów narodowych opiera się nie tylko na normach, ale także ma odniesienie do pozostałych czynników - w tym wiedzy zbiorowej, mitów, wartości czy określonych cech narodowych kształtujących tożsamość aktorów.

W pierwszej części pracy ukazano istotę niepodległości Kosowa, koncentrując się na analizie samego pojęcia suwerenności oraz na prezentacji społecznego podłoża konfliktu między Serbami a Albańczykami, który rozpatrywano w kategoriach niezgodności między zasadą prawa narodów do samostanowienia a integralnością terytorialną. Druga część jest próbą analizy na przykładzie Kosowa konkretnych wyznaczników suwerenności, takich jak niezależna władza, terytorium i ludność.

\section{ISTOTA SPOŁECZNEJ KONSTRUKCJI NIEPODLEGŁOŚCI KOSOWA}

W zrozumieniu istoty i specyfiki społecznej konstrukcji niepodległości Kosowa ważne jest wskazanie czynników, które wpłynęły na redefinicję pojęcia suwerenność. Dodatkowo suwerenność należy analizować jako normę społeczną, regulującą relację aktorów w strukturze. Norma powstaje w wyniku powtarzalnej praktyki międzynarodowej i zaakceptowania jej przez aktorów środowiska międzynarodowego. Kiedy dochodzi do łamania norm, skutkuje to interwencją niezadowolonej społeczności międzynarodowej. Normy wprowadzają porządek i pewnego rodzaju przewidywalność. Ich ochrona jest fundamentalna dla równowagi struktury. Paradoksem jest sytuacja, kiedy funkcjonowanie jednej normy może prowadzić do łamania drugiej. W przypadku Kosowa występuje wyraźna niezgodność pomiędzy zasadą samostanowienia narodów a zasadą integralności terytorialnej państwa, co wywołało konflikt o podłożu etnicznym i wymusiło reakcję ze strony makrostruktury. Sytuacja konfliktowa jest pochodną rozbieżnych interesów stron zainteresowanych. Oba społeczeństwa (kosowskich Albańczyków i Serbów) posiadają określoną tożsamość, przez co identyfikują swoje interesy i nadają im hierarchię priorytetów. Dla Serbów najważniejszym interesem będzie nierozerwalność granic, natomiast dla Albańczyków możliwość stworzenia własnego państwa. Tożsamość jest pochodną kultury narodowej, wartości społecznych, dziedzictwa kulturowego. Wymienione czynniki decydują o specyfice danego aktora i wpływają na jego zachowania w strukturze. Kosowo, podobnie jak każdy podmiot stosunków międzynarodowych określający siebie mianem państwa, należy analizować biorąc pod uwagę takie kategorie, jak terytorium, ludność i władza. Niestety, niezależność Kosowa nadal 
pozostaje dyskusyjna. Jego terytorium jest obszarem spornym i przez Serbów uważane jest za integralną część państwa. Współzamieszkiwanie jednego terytorium przez dwa zwaśnione narody dostarcza tylko dodatkowych problemów i blokuje rozwój państwa. Władze Kosowa korzystają z ogromnego wsparcia (nie tylko finansowego) ze strony środowiska międzynarodowego.

Pojęcie suwerenności państwowej nie jest statyczne, stałe i absolutne, ale społeczne. W ujęciu konstruktywistów to normy określają, jakie warunki o charakterze materialnym i społecznym powinny być spełnione, aby nastąpiło uznanie państwowości. Zasada suwerenności jest sformalizowaną normą instytucją, która powstała $\mathrm{w}$ wyniku działań państw ${ }^{1}$. Wzajemne uznanie suwerenności stanowi potwierdzenie związku i przynależności narodu do terytorium, wpływa na umocnienie i stabilizację interakcji między państwami. Normy określają, jakie konkretnie warunki decydują o uznaniu suwerenności przez inne państwa ${ }^{2}$. Konflikt o niepodległość Kosowa pokazuje, że kwestia suwerenności nadal pozostaje dyskusyjna. Całkowicie subiektywne postrzeganie rzeczywistości przez strony sporu powoduje, że powołują się one na dwie sprzeczne zasady, funkcjonujące w świadomości społeczeństw jako element normy międzynarodowej odnoszącej się do suwerenności. Albańczycy odwołują się do zasady nieingerencji i prawa do samostanowienia, natomiast Serbowie przywołują kwestie związane $\mathrm{z}$ jednością terytorialną ${ }^{3}$.

Okazuje się, że nie bez znaczenia jest także intersubiektywne postrzeganie problemu przez środowisko międzynarodowe. Dmitry Rogozin (wicepremier Federacji Rosyjskiej), stwierdził, że Rosja krytycznie ocenia Deklarację Niepodległości z 2008 roku i nie zamierza zmienić swojego stanowiska w tej kwestii. Podkreślił, że niepodległość Kosowa narusza zasadę integralności terytorialnej i jest sprzeczna z prawem międzynarodowym ${ }^{4}$. Stanowisko Rosji wydaje się być uzasadnione. Jako jeden $\mathrm{z}$ aktorów sekurytyzujących uważa suwerenność Kosowa za zagrożenie dla swoich interesów. Obawia się fragmentaryzacji wieloetnicznego państwa oraz obudzenia zamrożonych konfliktów (szczególnie w Abchazji, Osetii Południowej oraz Naddniestrzu).

Punktem wyjścia do rozważań na temat niepodległości Kosowa jest zbadanie suwerenności jako społecznej konstrukcji. Traktat westfalski, który został podpisany po wojnie trzydziestoletniej, zdefiniował pojęcie suwerenności. Określił ją jako organizację polityczną, wykluczając wpływ podmiotów zewnętrznych na struktury władzy na określonym terytorium. Państwo powinno

${ }^{1}$ J. Czaputowicz, Teorie stosunków międzynarodowych. Krytyka i systematyzacja, Warszawa 2007, s. 321.

${ }^{2}$ Ibidem, s. 322.

${ }^{3}$ A. Curanović, Samostanowienie, a integralność terytorialna - konsekwencje niepodległości Kosowa, http://www.stosunkimiedzynarodowe.info/artykul,47,Samostanowienie_a_integralnosc_terytorialna_konsekwencje_niepodleglosci_Kosowa.html.

${ }^{4} \mathrm{http}$ ///english.ruvr.ru/2012_11_28/Russia-s-Kosovo-stance-remains-unchanged-deputy-PM/. 
być niezależne i samodzielne de iure, ale także de facto autonomiczne ${ }^{5}$. Można stwierdzić, że suwerenność ma mieć wymiar wewnętrzny i zewnętrzny. Pierwszy oznacza, że państwo jest najwyższą władzą polityczną w społeczeństwie. W tym znaczeniu to właśnie państwo (a nie żaden inny podmiot) ma prawo do podejmowania decyzji wiążących. Podmiot ten ma legitymizację społeczną i jest posiadaczem uprawnień wynikających ze sprawowania władzy zwierzchniej. Uprawnienia władzy zależą od systemu politycznego. Nie można stwierdzić, że państwa demokratyczne są mniej suwerenne od państw totalitarnych. Holistyczny stosunek do suwerenności nie pozwala na gradację niepodległości. Opowiadając się za tym podejściem, sprawa wydaje się prosta - albo państwo posiada suwerenność, albo nie jest państwem. Alexandr Wendt zauważa jednak, że „,(..) empiryczna państwowość może istnieć bez państwowości prawnej"6. Suwerenność zewnętrzna oznacza brak jakiejkolwiek innej władzy stojącej wyżej niż państwo (np. organizacja międzynarodowa).

Idea suwerenności narodu i prawo do samostanowienia, dorobek epoki Oświecenia, wpisuje się w nurt liberalizmu. Idea ta znalazła odzwierciedlenie w rewolucji francuskiej. Zarówno jednostka, jak i wspólnota (naród) mają prawo samodzielnie decydować o swojej przyszłości. Granicę tej wolności stanowi wolność innych osób. Zasada ta chętnie była wykorzystywana przez nacjonalizm, który szczególnie silne był zauważalny w XIX wieku, kiedy w całym regionie Europy Południowej i Środkowo-Wschodniej zaczęła rozbudzać się świadomość narodowa, a coraz większe znaczenie miała odmienność językowa, kulturowa i religijna. Naród przestał być utożsamiany wyłącznie z uprzywilejowanymi i nielicznymi elitami społecznymi. Proces ten był bardzo widoczny w przypadku mniejszości białoruskiej i ukraińskiej, zamieszkujących Rosję i Austro-Węgry ${ }^{7}$.

W XX wieku suwerenność nabrała nowego znaczenia i coraz częściej była interpretowana jako możliwość decydowania o własnym losie, warunkach życia oraz kreowania własnej przyszłości. Zmiany w sposobie ujmowania suwerenności wynikają z nowego postrzegania idei sprawiedliwości i autorytetu władzy ${ }^{8}$. Zasada ta po raz pierwszy została przedstawiona w 1919 roku podczas konferencji pokojowej w Paryżu. Przemówienie prezydenta Woodrowa Wilsona wygłoszone do Kongresu USA 8 stycznia 1918 roku odegrało duży wpływ na określenie zasady samostanowienia narodów. Pięć pierwszych punktów odnosiło się do zasad ogólnych ładu powojennego - w tym wolności żeglugi, równości handlu, rozstrzygnięcia sporów kolonialnych. Kolejnych osiem mówiło o konkretnych roz-

\footnotetext{
${ }^{5}$ S.D. Krasner, Sovereignty organized hypocrisy, Princetown 1999, s. 4.

${ }^{6}$ A. Wendt, Społeczna teoria stosunków międzynarodowych, Warszawa 2008, s. 198.

${ }^{7}$ M. Missala, Raport: Samostanowienie narodów, Narody bez państw, „Puls świata”, 2004, $\mathrm{nr} 5$, http://www.puls-swiata.subnet.pl/artykul.php?id=8\&id_art=292.

${ }^{8}$ D. Philpott, Ideas and the Evolution of Soveregnity, w: S.H. Hashmi (red.), Sovereignity Change and Persistance in International relation, The Pennsylvania 1997, s. 16.
} 
wiązaniach geopolitycznych, dotyczących Rumunii, Serbii, Czarnogóry, Austro-Węgier, Turcji. Wilson wierzył, że każdy naród ma prawo do stworzenia swojego państwa oraz zdefiniowania własnego statusu społecznego, kulturowego i gospodarczego'.

W 1941 roku w Karcie Atlantyckiej stwierdzono, że nie można dopuścić do sytuacji, w której zmiany terytorialne nie są zgodne z wolą poszczególnych narodów $^{10}$. Po II wojnie światowej coraz więcej podmiotów zaczęło starać się o suwerenność. Dążenia niepodległościowe szczególnie nasiliły się wraz z rozwojem ruchów dekolonizacyjnych w Azji i Afryce. Jednak niepodległość miała bardziej charakter prawny niż empiryczny. Prawo do samostanowienia zostało podniesione na forum ONZ i wpisane do Karty Narodów Zjednoczonych. Zgodnie $\mathrm{z}$ artykułem 1 organizacja stawia sobie za cel ,(...) rozwijanie pomiędzy narodami przyjaznych stosunków opartych na poszanowaniu zasady równouprawnienia i samostanowienia narodów oraz stosowaniu innych odpowiednich środków dla umocnienia powszechnego pokoju" "11. Dodatkowo powoływano się na wspomnianą zasadę w paktach z 1966 roku, deklaracji ONZ dotyczącej przyznania niepodległości państwom i narodom kolonialnym ${ }^{12}$. Zgodnie $\mathrm{z}$ ostatnim dokumentem każde państwo ma prawo do samostanowienia, problemy gospodarcze czy społeczne nie powinny stanowić pretekstu dla odmówieniu państwu uznania jego niepodległości. Za niezgodne z prawem uznano próby dezintegracji narodowej czy też podejmowanie działań mających na celu rozbicie jedności narodowej przez podmioty zewnętrzne.

Redefinicja pojęcia suwerenności w sferze stosunków międzynarodowych $\mathrm{i}$ istnienie zasady odpowiedzialności państw za ochronę doprowadziły do zmiany interpretacji prawa do użycia siły. Pojawia się coraz większa złożoność czynników wpływających na decyzję o interwencji międzynarodowej innych państw czy ich koalicji. Integralność terytorialna, jeszcze do niedawna nadrzędna zasada regulująca stosunki międzynarodowe, została wyparta przez zasadę odpowiedzialności za ochronę (responsibility to protect) ${ }^{13}$. Zmiany w określaniu suwerenności są wywołane $\mathrm{z}$ jednej strony narastającymi zależnościami pomiędzy państwami (i innymi podmiotami stosunków międzynarodowych), z drugiej, nasilającymi się zagrożeniami o różnym charakterze ze strony środowiska międzynarodowego ${ }^{14}$. Pochodną zwiększenia poczucia zagrożenia jest wzrost zobowiązań państw, wynikający z przyjęcia traktatów międzynarodowych i uczestnictwa w or-

\footnotetext{
${ }^{9}$ W. Wilson, Delivered in Joint Session, 08.01.1918, http://homepage.mac.com/hakan,_danielsons/ wilsons \%2014.pdf.

${ }^{10}$ The Atlantic Charter, 14.08.1941, http://www.nato.int/cps/en/natolive/official_texts_16912.htm.

${ }^{11}$ Karta Narodów Zjednoczonych, 26.06.1945, http://www.unic.un.org.pl/dokumenty/karta_onz.php.

${ }^{12}$ Ibidem.

${ }^{13}$ P. Piasecka, Prawnomiędzynarodowe aspekty użycia sity we wspótczesnych stosunkach międzynarodowych, „Bezpieczeństwo międzynarodowe”, 2011, nr 11, s. 1.

${ }^{14}$ J. Dobrowolska-Polak, Międzynarodowa solidarność. Operacje pokojowe ONZ, NATO i UE, „IZ Policy Paper", Poznań 2008, nr 3, s. 11, http://www.iz.poznan.pl/news/125 pp\%20nr\%203\%20P.pdf.
} 
ganizacjach. Działania te w decydowanej większości mają za zadanie zwiększenie bezpieczeństwa państw. Należy jednak pamiętać, że przekazywanie części uprawnień organizacjom międzynarodowym jest paradoksalnie wyrazem ich suwerenności, gdyż pozwala państwom samodzielnie decydować o swoim losie $\mathrm{i}$ jest wyrazem ich woli ${ }^{15}$. Wynika to $\mathrm{z}$ niezależności konstytucyjnej państw, która objawia się zarówno jako wewnętrzna, jak i zewnętrzna możliwość określania własnych kompetencji. Uczestnictwo w organizacjach międzynarodowych - powszechnych jak i regionalnych - ma na celu wzrost bezpieczeństwa państw. W związku z tym ONZ dopuszcza możliwość reagowania w sytuacji, gdy dojdzie do ludobójstwa, czystek etnicznych lub zbrodni przeciwko ludzkości. Po wyczerpaniu środków dyplomatycznych zgłasza „(...) gotowość do podjęcia działania w sytuacji, gdy środki pokojowe okażą się niewystarczające, a władze krajowe wyraźnie i jednoznacznie niezdolne do ochrony swej ludności przed ludobójstwem, zbrodniami wojennymi, czystkami etnicznymi oraz zbrodniami przeciw ludzkości, akcji zbiorowej, przeprowadzonej w odpowiednim czasie i w sposób zdecydowany (...)"16.

Sankcje i interwencje międzynarodowe przeprowadzone przez społeczność międzynarodową zakwestionowały absolutną suwerenność. Interwencją sensu largo określa się wpływ na niepodległe państwo i jego sprawy wewnętrzne. W definicji tej mieści się zarówno każda działalność ograniczająca aktywność państwa, ale też zaniechanie działania. Celem interwencji jest chęć zmiany lub podtrzymania konkretnej struktury politycznej oraz w skrajnych przypadkach uzyskanie wpływu na podejmowanie decyzji przez aparat państwowy. Według Petera Schroedera interwencja to świadome wykorzystanie określonych środków o różnym charakterze (w tym politycznym, ekonomicznym i wojskowym) w celu uzyskania wpływu na politykę wewnętrzną i zagraniczną innego państwa ${ }^{17}$. Rażące łamanie praw człowieka czy czystki etniczne pozwalają na zastosowanie interwencji międzynarodowej. Międzynarodowa Komisja ds. Interwencji i Suwerenności Państw jako obowiązek społeczności międzynarodowej wskazała ochronę ludności. Obowiązek ten wynika zarówno z praktyki państw, jak i organizacji międzynarodowych i jest realizowany zgodnie $\mathrm{z}$ koncepcją parasola (umbrella concept). Składa się z trzech elementów: zapobiegania naruszeniom, reagowania na łamanie praw człowieka i odbudowy. Wszystkie wymienione elementy mają na celu przywrócenie bezpieczeństwa ludności ${ }^{18}$.

Interwencja sensu stricte to celowe działanie państwa, uwzględniające środki wojskowe, podjęte wbrew woli innego państwa i mające na celu trwałe

\footnotetext{
${ }^{15}$ P. Piasecka, op. cit., s. 5-6.

${ }^{16}$ Dokument Końcowy Szczytu 2005, A/60/L.1, 20.09.2005 r., http://www.unic.un.org.pl/szczyt2005/dokument koncowy 4.php.

${ }_{17}$ A. Domagała, Interwencja humanitarna $w$ stosunkach międzynarodowych, Wrocław 2008 , s. 7-22.

${ }^{18}$ J. Dobrowolska-Polak, op. cit. s. 18.
} 
zmiany w jego funkcjonowaniu. Jerzy Ciechański za interwencję uważa działania państwa poza własnymi granicami, na terytorium innego państwa, z zastosowaniem sił zbrojnych (w tym bombardowanie obcego państwa, rozlokowanie jednostek wojskowych na jego terytorium). Z przedstawionej analizy wynikają następujące wnioski odnoszące się do pojęcia interwencji. Po pierwsze, podmiotem interwencji jest zawsze państwo (grupa państw, czasami organizacja międzynarodowa). Po drugie, interwencja prowadzi do naruszenia więzi występujących $\mathrm{w}$ środowisku międzynarodowym. Jest przejawem zastosowania środków wyjątkowych, a w myśl prawa międzynarodowego jest nielegalna. Po trzecie, zawsze jest uznawana za środek przymusu. Po czwarte, interwencja często wiąże się $\mathrm{z}$ zastosowaniem środków militarnych ${ }^{19}$.

Należy zauważyć, że coraz częściej praktyka międzynarodowa zupełnie nie przystaje do wyznaczonych norm. Prawo do samostanowienia narodów, ujęte w rezolucji Zgromadzenia Ogólnego ONZ nr 2625 z dnia 24 października 1970 roku, nie obejmuje secesji części państwa macierzystego. Mimo to, Międzynarodowy Trybunał Sprawiedliwości w opinii dotyczącej powstania Kosowa nie dopatrzył się aktu bezprawia ${ }^{20}$. Potwierdza to rozbieżność między praktyką a pożądanymi zachowaniami wyznaczonymi w normach. Sama interwencja w Kosowie potwierdza zaś zasadę, że jeśli intersubiektywna norma nie jest korzystna dla podmiotów makrostruktury, to jej naruszenie jest usprawiedliwione.

Cyk1 rozwojowy normy obejmuje trzy etapy. Pierwszy to okres tworzenia normy i uzyskania aprobaty jak największej liczby aktorów. Etap drugi obejmuje socjalizację państw, prowadzącą do wzrostu liczby podmiotów akceptujących normę. Ostatni etap polega na internalizacji normy i przyjęciu jej za oczywistą $^{21}$. W przypadku Kosowa doszło do złamania powszechnie akceptowanych norm w trzecim stadium. Podnoszona (przynajmniej oficjalnie) kwestia łamania praw człowieka w rejonie konfliktu czy prawa do samostanowienia jest przejawem naruszenia w pełni rozwiniętej normy. Interwencja NATO, określana dyplomatycznie przez sam sojusz jako „wzbudzająca gorące spory polityczne”, $\mathrm{w}$ istocie była nielegalna ${ }^{22}$. Wydaje się, że NATO musiało działać wobec bezczynności ONZ. Jednak nawet działania nielegalne znajdują swoje usprawiedliwienie. Według Pascala Milo (ministra obrony Albanii) „(...) interwencja sojuszu w Kosowie pozwoliła uniknąć katastrofy humanitarnej, przywróciła poszanowanie życia ludzkiego i praw człowieka, stanowiła przejaw filozofii naszych czasów"23. Gdy serbsko-albański konflikt etniczny w Kosowie zaognił się i stał się nie do przyjęcia przez opinię publiczną, status prawnomiędzynarodowy Ko-

\footnotetext{
${ }^{19}$ A. Domagała, op. cit., s. 18-19.

${ }^{20}$ M. Wasiński, Hierarchia norm (zobowiazań) $w$ prawie międzynarodowym, w: Prawo międzynarodowe publiczne (wyklad 2010/2011) - Część szósta, http://www.grocjusz.edu.p1/Materials/mw_w_pm 2011-6.pdf.

${ }^{21}$ J. Czaputowicz, op. cit., s. 315.

${ }^{22} \mathrm{http} / / /$ www.nato.int/nato static/assets/pdf/pdf publications/20120117 21st pol.pdf.

${ }^{23}$ J. Potocki, Poligon Kosowo, „Wprost”, http://www.wprost.pl/ar/2368/Poligon-Kosowo/.
} 
sowa nie pozwalał na zastosowanie zasady zbiorowej samoobrony ${ }^{24}$. Weto Chin i Rosji uniemożliwiło interwencję przeprowadzoną przez Organizację Narodów Zjednoczonych.

Coraz bardziej dokuczliwy stawał się problem dotyczący pogodzenia dwóch społecznie uznawanych norm - nieingerencji i praw człowieka. Z tym ostatnim związana jest kwestia etniczna. Podłożem konfliktu w Kosowie jest występowanie dwóch grup etnicznych na jednym terytorium. Według Anthony'ego Giddensa etniczność odnosi się do kulturowych praktyk i zapatrywań danej społeczności ludzkiej. Różnice te występują w języku, historii, pochodzeniu, religii ${ }^{25}$. Co szczególnie ważne dla konfliktu w Kosowie, różnice etniczne są w pełni wyuczone, a sama etniczność jest wytwarzana przez ludzi i odtwarzana w czasie. Zatem jest zjawiskiem czysto społecznym, a sam konflikt wynika z różnic $\mathrm{w}$ wykreowaniu własnej tożsamości. Kiedy chociaż jedna $\mathrm{z}$ grup nie chce pokojowo współżyć na jednym terenie, ani ulec asymilacji, dochodzi do konfliktu. W przypadku Albańczyków i Serbów trudno jest oczekiwać pierwszych dwóch rozwiązań. Pozostaje zatem konflikt o rewizję granic i secesję terytorium.

Zasada samostanowienia jest nierozerwalnie związana $\mathrm{z}$ ochroną praw człowieka (w tym określonych grup etnicznych). Artykuł 1 Międzynarodowego Paktu Praw Gospodarczych, Społecznych i Kulturalnych wyraźnie pokazuje tę zależność. Zgodnie z jego zapisami „,...) wszystkie narody mają prawo do samostanowienia. Z mocy tego prawa swobodnie określają one swój status polityczny i zapewniają rozwój gospodarczy, społeczny i kulturalny”26. Podstawowym zadaniem państwa jest zatem zapewnienie bezpieczeństwa swoim obywatelom. Zgodnie z założeniem, że państwo jest społeczną konstrukcją, nie wystarczy, że będzie ono w stanie zapewniać swoim obywatelom bezpieczeństwo przed zagrożeniem zewnętrznym, ale musi także spełniać funkcję społeczną stwarzać warunki do życia i rozwoju. Poza tym, poprzez bezpieczeństwo rozumiemy również zapewnienie ochrony kultury narodowej, umożliwienie kontynuowania tradycji i przekazywania konkretnych doświadczeń historycznych obywatelom. Można stwierdzić, ze istnieją dwa rodzaje wyznaczników suwerenności. Pierwsze mają charakter materialny (terytorium, władza, ludność). Są one niezmienne i bezwzględnie istniejące. Przyjęcie takiego modelu analizy społecznej konstrukcji suwerenności thumaczy związek określonych grup z terytorium. Uzasadnione jest przywiązanie Albańczyków czy Serbów do terytorium Kosowa, ponieważ stanowi to element ich tożsamości ${ }^{27}$. Druga grupa czynników

${ }^{24}$ G. Kostrzewa-Zorbas, Poczatek czy koniec epoki? Wojna o Kosowo, Stany Zjednoczone, NATO i bezpieczeństwo europejski, w: A. Magdziak-Miszewska (red.), Świat po Kosowie, Warszawa 2000, s. 52.

${ }^{25}$ A. Giddens, Socjologia, Warszawa 2007, s. 270

26 Międzynarodowy pakt praw gospodarczych, społecznych $i$ kulturalnych, Nowy Jork, 19.12.1966, Dz.U z dnia 29.12.1977.

${ }^{27}$ G. Sørensen, Sovereignty: Change and Continuity in a Fundamental Institutio, w: R. Jackson (red.), Sovereignty At The Millennium, Oxford 1999, s. 171. 
ma charakter niematerialny i jest związana ze społeczeństwem. Wynika to $\mathrm{z}$ faktu, że w państwach demokratycznych najwyższym suwerenem jest lud $\mathrm{d}^{28}$. $\mathrm{Z}$ podanym podziałem wiąże się pojmowanie bezpieczeństwa, które powinno być zapewnione w celu przetrwania narodu. Bezpieczeństwo fizyczne rozumiane jest jako obrona oraz ochrona przed zjawiskami zagrażającymi stabilności przy użyciu wyspecjalizowanych sił i konkretnych środków. Bezpieczeństwo to ma wymiar cywilny lub militarny ${ }^{29}$. Jego zapewnienie jest kluczowe dla przetrwania materialnego państwa. Jednak w przypadku konfliktu o Kosowo, szczególne znaczenie ma bezpieczeństwo ontologiczne. Już od wieków istota ludzka, poza zaspokajaniem podstawowych potrzeb zapewniających przetrwanie fizyczne, boryka się z licznymi problemami o charakterze metafizycznym, świadomościowym i tożsamościowym ${ }^{30}$. Wspomniane rozterki mają charakter niematerialny i irracjonalny. Bezpieczeństwo ontologiczne w wymiarze jednostkowym jest cyklem procesów obejmującym różne elementy sfer życia człowieka, których celem jest właściwe funkcjonowanie istoty ludzkiej. Sprowadza się do eliminacji zagrożeń, które mogłyby mieć negatywny wpływ na istnienie jednostki ${ }^{31}$. W przypadku narodu bezpieczeństwo ontologiczne wiąże się z zapewnieniem ochrony tożsamości narodowej, kultury, języka. Działania sprowadzają się do obrony elementów charakterystycznych dla danego narodu, decydujących o jego indywidualnych cechach, wyróżniających go spośród innych narodów. Wszystkie wymienione elementy są ze sobą związane. Świadomość odmienności (wyjątkowości) danej kultury, historii czy języka wpływa na kształtowanie tożsamości narodowej. Ta z kolei ma szczególne znaczenie dla określenia interesów narodowych. Zauważmy, że odmienność kulturowa Serbów i Albańczyków jest niezwykle wyraźna, a konflikt interesów w walce o Kosowo bardzo silny. Tożsamość jest zatem kluczowa dla zrozumienia interesów obu narodów.

Tożsamość według Zygmunta Baumana jest „(...) czymś, co się konstruuje, i co można (przynajmniej w zasadzie) konstruować na różne sposoby, i co nie zaistnieje w ogóle, jeśli się jej na któryś ze sposobów nie skonstruuje" ${ }^{\text {"32 }}$. Tożsamość nie jest jednak produktem jednej instytucji czy grupy społecznej, ale powstaje dopiero $\mathrm{w}$ wyniku interakcji ze środowiskiem międzynarodowym. Powoduje to, że tożsamość staje się elementem zarówno subiektywnego, jak i intersubiektywnego postrzegania rzeczywistości przez aktorów. I wcale nie oznacza, że postrzeganie to musi być identyczne. Wzajemne postrzeganie Albańczyków i Serbów jest odmienne od tego, które funkcjonuje w świadomości obu narodów na swój temat. Serbowie postrzegają Albańczyków jako nie-

\footnotetext{
${ }^{28}$ Ibidem, s. 182.

${ }^{29}$ S. Koziej, Bezpieczeństwo: istota, podstawowe kategorie i historyczna, „Bezpieczeństwo narodowe", 2011, nr 18, s. 34.

${ }^{30}$ Ibidem.

${ }^{31}$ A. Giddens, Nowoczesność i tożsamość. „Ja” i spoleczeństwo w epoce późnej nowoczesności, Warszawa 2001, s.15.

${ }^{32}$ Z. Bauman, Dwa szkice o moralności ponowoczesnej, Warszawa 1994, s. 9.
} 
wdzięcznych zdrajców. W serbskiej świadomości ciągle żywy jest obraz tureckiego okupanta oraz antychrześcijańskie represje. Kosowski Albańczyk jest przedstawiany jako muzułmański zaborca. W czasach tureckich doszło do masowego niszczenia obrazów poprzez wydrapywanie oczu uwiecznionym na nich postaciom. W wierszu „Symonida” (M. Rakić) oprawcą obrazu jest Albańczyk, ponieważ w serbskiej świadomości funkcjonuje jako tchórzliwy barbarzyńca, podobnie jak Turek ${ }^{33}$. Albański stereotyp Serba opiera się na przekonaniu, że jest on najniebezpieczniejszym i podstępnym wrogiem, który dąży do upokorzenia i etnicznego wyniszczenia narodu albańskiego ${ }^{34}$.

Tożsamość jest z zasady subiektywna, istnieje na poziomie jednostkowym i zależy od samoświadomości aktora. Znaczenie tożsamości będzie zależeć od tego, czy inni aktorzy przedstawiają dany podmiot lub zjawisko w podobny sposób. Można stwierdzić, że jej jakość jest także intersubiektywna lub makrosystemowa. Tożsamości są więc kreowane na poziomie wewnętrznym i zewnętrznym. Tożsamość jest właściwa samoorganizującym się homeostatycznym strukturom, które czynią aktorów wyróżniającymi się podmiotami. Jej podstawę stanowią materialne wyznaczniki, ale to niematerialne przesłanki decydują o specyfice tożsamości. Oznacza to, że każdy naród posiada cechy właściwe, mające decydujący wpływ na jego tożsamość. Może być to język, kultura, historia $^{35}$. W tym ujęciu łatwo zauważyć, że tożsamość osobista Albańczyka różni się od tożsamości Serba. Oba narody posługują się innym językiem (serbski, albański), wyznają inne religie (chrześcijaństwo, islam) i mają odmienną obyczajowość.

To, co jest istotne dla tożsamości osobistej, to tak zwana jaźń. Naród nie może istnieć, jeśli nie ma świadomości i pamięci historycznej. Tożsamość nie jest stanem, a procesem pozwalającym na artykulację interesów. Interes umożliwia zatem zaspokojenie potrzeb wynikających bezpośrednio $\mathrm{z}$ tożsamości ${ }^{36}$. Zarówno Serbowie, jak i Albańczycy wykorzystują historyczne tło swojej tożsamości i kultury do wyartykułowania konkretnego interesu (udokumentowania przynależności obszaru Kosowa do swojego narodu). Dzięki temu mogą zaspokoić potrzeby, które mają swoją genezę w tożsamości. Emocjonalny, historyczny i kulturowy związek z ziemią nie pozwala na oddanie jej innemu narodowi, ponieważ jest on częścią ich samookreślenia.

Największy wpływ na kształtowanie tożsamości ma przywoływany już wielokrotnie czynnik etniczny. Stanowił on podstawę dążeń narodów bałkańskich do kreowania własnej państwowości, poszukiwania ciągłości historycznej, tworzenia obyczajowości. Poczucie odrębności etnicznej wyrażało się w różny sposób i w konsekwencji przybierało odmienne formy. Wynikało to z rozwoju

${ }^{33}$ M. Rakić, Symonida, http://kns.uni.lodz.pl/index2.php?option=com_content\&do_pdf=1\&id=194.

34 J. Mindak, Polityczne emocje Batkańczyków, „Więź”, 1999, nr 12 http://www.wiez.com.pl/index.php?s =miesiecznik_opis\&id $=169 \& \mathrm{t}=3809$.

${ }^{35}$ A. Wendt, Spoteczna ..., s. 212.

${ }^{36}$ Ibidem, s. 218. 
świadomości społecznej oraz możliwości jej manifestowania. Ciągłość etniczna, znajdująca swój przejaw w wymiarze kulturowym i historycznym, ostatecznie zdefiniowała tożsamość aktora w makrostrukturze. Nie sposób nie zauważyć, że to głównie różnice etniczne determinują odmienność postrzegania Serbów i Albańczyków. Dzięki tak istotnym różnicom oba narody mogą dokonać podziału na „my” i „oni”. Ze względu na tak daleko posuniętą manipulację własną tożsamością i wykorzystywanie jej do kreowania wspomnianego interesu, należy zadać pytanie, czy kultura narodowa Serbów i kosowskich Albańczyków jest autonomiczna, czy raczej podporządkowana celom narodowym ${ }^{37}$ ? Odpowiedź na to pytanie nie jest prosta. Oczywiście można stwierdzić, że kultura narodowa jest między innymi po to, żeby była wykorzystywana dla realizacji celów narodowych. $Z$ drugiej strony, jak łatwo zauważyć w przypadku kosowskich Albańczyków, w momencie, w którym pojawia się szansa realizacji państwa narodowego, następuje proces rozszerzania bazy etnicznej w sensie terytorialnym (tu na obszar Kosowa) i poszukiwanie w oparciu o przesłanki historyczne argumentów uzasadniających taki stan rzeczy, kosztem interesów innych państw (Serbii). Jak widać tożsamość i interes są ze sobą powiązane i wzajemnie się determinu$\mathrm{ją}^{38}$. Tożsamość implikuje interesy, ale nie da się do nich zredukować. Interesy pozwalają określić, jaki cel mają aktorzy. Wyznaczają motywację, która pozwala uargumentować zachowanie (jak w przytoczonym przykładzie). Tożsamość umożliwia zdefiniowanie interesów, ponieważ tłumaczy, kim jest aktor. Dopóki nie jest to określone, nie można stwierdzić, jakie są jego potrzeby. Oczywiście, nie zawsze tożsamość musi przekładać się na interes, ponieważ nie każdy interes musi być wyartykułowany. Poza tym, to, kim aktor jest, nie zawsze musi się pokrywać z tym, kim chciałby być. Tożsamość określa stan rzeczywisty, interes stan pożądany ${ }^{39}$.

Interesy obiektywne są potrzebami, które muszą zostać zaspokojone dla potrzymania tożsamości. Istnieją one często podświadomie, niezrealizowane zagrażają przetrwaniu lub ciągłości tożsamości. Interesy obiektywne są pierwotne i absolutnie konieczne dla istnienia tożsamości charakterystycznej dla danego aktora. Jeśli zanikną, aktor może zmienić swoją tożsamość. Widoczny pozostaje związek między interesami obiektywnymi a interesem narodowym. Można stwierdzić, że są one siłą, która popycha państwa do określonych zachowań. Interes narodowy można określić jako zespół stałych celów, które naród chce osiągnąć. Obejmują one ochronę przed agresją ze strony innego państwa, utrzymanie stabilności zewnętrznej i wewnętrznej oraz utrzymanie odpowiedniego standardu życia, pozwalającego jednostce na zaspokajanie swoich potrzeb $^{40}$. Interes narodowy jest skoncentrowany na zapewnieniu przetrwania fi-

\footnotetext{
${ }^{37}$ F. Gołembski, Stosunki kulturalne na Bałkanach, Warszawa 2008, s. 68

${ }^{38}$ Ibidem, s. 40

${ }^{39}$ A. Wendt, Spoteczna..., s. 218.

${ }^{40}$ Ibidem, s. 220-224.
} 
zycznego, autonomii, dobrobytu gospodarczego i poczucia własnej wartości. Najważniejsze znaczenie ma przetrwanie fizyczne i autonomia. Przetrwanie ma charakter wyłącznie zbiorowy, ponieważ jednostka nie może być nośnikiem tożsamości narodowej. Wymienione interesy muszą zostać zaspokojone, jeśli struktury państwa mają być bezpieczne. Stanowia one wytyczne dla polityki zagranicznej. W wyjątkowych okolicznościach mogą mieć sprzeczne implikacje, które wymuszają ustalenie interesów priorytetowych w określonym czasie, ale ostatecznie i tak muszą być zrealizowane. Państwa, które tego nie uczynią, prędzej czy później przestaną istnieć. Aktorzy państwowi muszą podejmować określone działania dla ochrony swojej tożsamości. Dobrze, kiedy państwa są jej świadome, co pozwala na bezbłędne identyfikowanie ich potrzeb i na tej podstawie formułowanie interesów. Interesy subiektywne są bezpośrednią motywacją zachowań aktorów. Odnoszą się do tych przekonań, które są związane z zaspokojeniem swoich potrzeb. Można je określić jako preferencje lub gusta. Przez preferencje nie należy rozumieć zachowań, ale raczej motywy. Poza tym interesy subiektywne są zorientowane głównie na cel, marginalne znaczenie ma strategia. Przyglądając się działaniom kosowskich Albańczyków, widać przede wszystkim nastawienie na osiągnięcie celu (stworzenie niepodległego państwa).

Jednym z głównych problemów, przed jakim stoi aktor, jest próba hierarchizacji interesów o charakterze obiektywnym i subiektywnym. Posiadanie własnego terytorium jest interesem absolutnie nadrzędnym $i$ jest związane z państwotwórczą rolą narodu. Należy pamiętać, że występują dwa rodzaje relacji między narodem i państwem - pierwsza to narodotwórcza rola państwa, a druga to wspomniana wcześniej państwotwórcza rola narodu. Trudno wskazać ramy czasowe lub przestrzenne dominacji którejś z nich ${ }^{41}$. Często granica między nimi jest bardzo płynna i trudno ustali co było najpierw - państwo czy naród. Zgodnie z opinią Jaroslava Krejci istnieje pięć kryteriów wyodrębnienia narodu: terytorium, status polityczny, język, kultura i historia ${ }^{42}$. Wszystkie wymienione elementy mają znaczenie dopiero wtedy, gdy równolegle $\mathrm{z}$ nimi występuje świadomość narodowa, która wynika z samoidentyfikacji. W przypadku Serbów i Albańczyków możemy stwierdzić, że występują wszystkie elementy. Oba narody posiadają własny język, kulturę, historię i bardzo mocno rozbudzoną świadomość narodową. Problem w tym, że żyją na jednym terytorium i roszczą sobie do niego prawa.

Niepodległość państwa zależy zarówno od świadomości samych aktorów, jak i od uznania ze strony innych podmiotów państwowych. Istnieje obszerna grupa państw, która nie uznała niepodległości Kosowa, mimo percepcji kosowskich Albańczyków, którzy uważają się za niezależny od Serbii podmiot stosun-

${ }^{41}$ G. Michałowska, Współczesny nacjonalizm, a państwo, w: E. Haliżak, I. Popiuk-Rysińska (red.), Państwo we wspótczesnych stosunkach międzynarodowych, Warszawa, 1995, s. 15-27.

${ }^{42}$ J. Krejci, Ethnic problem in Europe, w: S. Ginter, M. Scotford Archer (red.), Contemporary Europe: Social Structures and Cultural Patterns, London 1978, s. 125. 
ków międzynarodowych. Sprawa jest o tyle skomplikowana, że percepcja serbskiego narodu jest zupełnie inna. Mamy więc do czynienia $\mathrm{z}$ dwoma punktami widzenia problemu Kosowa - intersubiektywną opinią środowiska międzynarodowego (które uznaje lub nie uznaje istnienie nowego podmiotu) oraz subiektywne stanowisko stron zainteresowanych (Serbów i kosowskich Albańczyków). Według tych pierwszych Kosowo jest nierozerwalnie związane z Serbią i nie ma prawa istnieć jako samodzielny byt. Należy się zastanowić, co wpływa na percepcję aktorów. Według Alexandra Wendta społeczna struktura składa się z trzech elementów - wspólnej wiedzy, materialnej podstawy i praktyki ${ }^{43}$. O ile materialne podstawy (źródła) mają fundamentalne znaczenie dla samego istnienia danej struktury, o tyle zbiorowa wiedza decyduje o specyfice danego bytu i kształtuje sposób odbioru przez niego rzeczywistości. Obie strony przedstawiają szereg dowodów, które mają potwierdzić i uwiarygodnić ich racje. Zgodnie z założeniami konstruktywizmu działania państw są determinowane przez interes narodowy, który każde państwo określa indywidualnie. Serbia określiła interes narodowy jako zachowanie integralności terytorialnej, który zostanie osiągnięty poprzez utrzymanie Kosowa. Interesy narodowe zależą zarówno od geopolitycznych determinantów, jak i od tego, jakie cechy wyróżniające posiada dany naród. Stąd na przykład przy analizowaniu konfliktu trudno pominąć wpływ albańskiego kodeksu honorowego, który kształtuje tożsamość tego narodu.

$\mathrm{Z}$ założenia interesy państw są egoistyczne, uwarunkowane historycznie i kulturowo ${ }^{44}$. Interes serbski może być zrealizowany tylko kosztem interesu albańskiego. Interesy mają zazwyczaj charakter materialny (np. kosowska ziemia), ale są generowane przez niematerialne czynniki (serbska historia, tradycja, dziedzictwo duchowe), które zostały ujęte w idee, normy lub wartości. Te czynniki znajdują odzwierciedlenie w faktach społecznych. Mianem faktów społecznych określa się aspekty życia społecznego, takie jak stan gospodarki czy też wpływ religii lub kultury, które tłumaczą działania jednostek. Durkheim uważał, że społeczeństwo to coś więcej niż tylko zbiór działań i interesów. Fakty społeczne mają charakter zewnętrzny i przymusowy - co znaczy, że działają poza jednostką i niezależnie od niej, ale determinują jej działanie ${ }^{45}$. Wpływ faktów na działanie i percepcję jednostki jest niezależny od jej woli. Często też jednostka całkiem bezwolnie ulega ich wpływom. Upraszczając, można założyć, że ludzie podporządkowują się wzorcom obowiązującym w danym społeczeństwie, a wiedzę zbiorową przyjmują za słuszną i obowiązującą ${ }^{46}$. Patrząc na konflikt o Kosowo, można dostrzec wpływ faktów społecznych na działanie obu stron. Wiedza historyczna, mity narodowe, wpływ religii i kodeksu honorowego kształtują działania jednostek, a co za tym idzie sterują działaniem społeczeństw. Stanowią

\footnotetext{
${ }^{43}$ A. Wendt, Constructing International Politics, ,International Security”, 1995 r., nr 1, s.73.

${ }^{44}$ A. Wendt, Spoteczna ..., s. 220.

${ }^{45}$ A. Giddens, Socjologia..., s. 33.

${ }^{46}$ Ibidem, s. 34.
} 
element wiedzy zbiorowej i genezę definiowania interesu narodowego. Żeby zrozumieć percepcję Albańczyków i Serbów, trzeba poddać analizie poszczególne fakty społeczne i wpływy kulturowe, które wpływają na świadomość narodów.

Strona serbska najchętniej powołuje się na kwestie historyczne, które najsilniej kreują tożsamość. Mity wytworzone w świadomości zbiorowej zawierają wiele płynnych elementów, motywów i toposów. Ukazują nastawienie Serbów do innych narodów, determinują ich politykę i przyczyniają się do określenia interesów (w tym integralności terytorialnej). Zrozumienie mitów narodowych i ich wciąż żywej obecności w kulturze pozwala na wytłumaczenie przywiązania do Kosowa. Mity pomagają określić wrogów oraz przyczyniają się do gloryfikacji poświęcenia w imię obrony tożsamości. Głównym celem mitów jest realizowanie interesu definiowanego jako przetrwanie narodu ${ }^{47}$. Patrząc na historię konfliktu o Kosowo, trudno dokonać analizy w oderwaniu od wszechobecnych mitów narodowych obu nacji. Po rozpadzie Jugosławii doszło do stworzenia warunków politycznych sprzyjających powstawaniu utworów muzycznych czy też literackich, czasami także prac naukowych, które gloryfikowały historię narodów SFRJ. Proces mitologizacji historii, rozbudzony między innymi przez nacjonalistyczne działania, dotyczył zarówno Serbów, jak i Albańczyków. Znaczenie mitu dla kształtowania tożsamości i postaw społeczeństw jest nieocenione. Mit bazuje na silnych emocjach i powoduje gwałtowne, często irracjonalne zachowania. Cechą charakterystyczną mitu jest szukanie powiązań między przeszłością i teraźniejszością. W przypadku mitów mamy do czynienia z całkowicie subiektywnym postrzeganiem rzeczywistości przez dany naród. Niestety, często ulegającym złudnej mispercepcji. Dobrym przykładem jest szukanie analogii między interwencją NATO w Kosowie a średniowieczną bitwą na Kosowym Polu ${ }^{48}$. Analiza mitów i historii pozwala zrozumieć subiektywne postrzeganie konfliktu przez Serbów i Albańczyków.

Kosowo zostało przyłączone do Serbii przez Stefana Nemanję w 1180 roku. W 1219 roku pierwszy koronowany władca Serbii otrzymał zezwolenie na utworzenie arcybiskupstwa $\mathrm{z}$ siedzibą w Žičy. Miejsce to miało znaczenie symboliczne: dokonywano tu koronacji serbskich władców ${ }^{49}$. W XIII wieku powstała cerkiew Świętych Apostołów koło Peći. Pierwszym centrum Serbii była Raszka. Nazwa związana jest z Rasem, czyli stolicą ziem serbskich należących do Kościoła. W II połowie XIII wieku jej funkcje zaczęły przejmować inne pałace, między innymi w Pristinie oraz ośrodki zlokalizowane głównie na obszarze Kosowa. Pod koniec XIII wieku Žiča została zniszczona przez Tatarów. Zmusiło

47 J. Bodawski, Serbski etno mit polityczny, http://www.nacjonalista.pl/2010/04/17/janbodakowski-serbski-etno-mit-polityczny/.

${ }^{48}$ W. Korczyński, Historyczno- kulturowe uwarunkowania serbsko- albańskiego konfliktu o Kosowo, http://www.mojeopinie.pl/historycznokulturowe_uwarunkowania_serbskoalbanskiego_konfliktu_o_kosowo,3,12229866124.

${ }^{4 \overline{9}} \mathrm{~W}$. Felczak, T. Wasilewski, Historia Jugosławii, Wrocław 1985, s. 109-111. 
to archiepiskopów do przeniesienia swojej siedziby do Peći. Mimo odbudowania Žičy, nigdy już do niej nie powrócili. Rozbudowa nowej siedziby doprowadziła w konsekwencji do utworzenia kompleksu Pecka Patrijaršija. W latach 30. XVI wieku patriarchat podporządkowany został arcybiskupstwu w Ochrydzie i oparł się panowaniu tureckiemu. Podboje tureckie na terenie Kosowa doprowadziły do likwidacji Patrijaršiji w 1766 roku. Ulokowanie Patrijaršiji w Peći spowodowało, że miejsce to zaczęło być uważane za "serbską Jerozolimę" "50. Oczywiście przytoczone określenie jest elementem mitologii narodowej, efektem celowego wyolbrzymiania faktów i przypisywania im ponadprzeciętnego znaczenia.

W ten sam sposób Serbowie tworzyli mit bitwy na Kosowym Polu. W XIV wieku Europa musiała bronić się przed inwazją turecką. Celem Turków była ekspansja na nowe terytoria i powiększenie terytorium Królestwa Osmańskiego. Oficjalnie działania tureckie miały charakter krucjaty, której celem miało być nawracanie na islam. 15 czerwca 1389 roku doszło do bitwy turecko-serbskiej na Kosowym Polu. Teoretycznie sukces odniosła armia turecka. Jednak w serbskiej świadomości bitwa miała dużo szerszy, metafizyczny wymiar i nie została ostatecznie rozstrzygnięta. Śmierć księcia Lazara Hrebeljanovicia odczytywana jest jako walka o ostateczną wolność (narodu i chrześcijaństwa) ${ }^{51}$. Turcy zwyciężyli w królestwie ziemskim, ale prawdziwa bitwa zostanie rozegrana dopiero w królestwie niebieskim. Szczególne jest także znaczenie śmierci Miloša Obilićia, przedstawianej jako ofiara za wiarę chrześcijańską. Wojownik zamordował sułtana $\mathrm{w}$ jego namiocie, sam tracąc życie z rąk straży ${ }^{52}$.

Mit walki na Kosowym Polu jest wciąż żywy. Pod koniec lat 80. wielką popularność zyskał serbski polityk Slobodan Milošević. Do historii przeszło jego wystąpienie, w którym padło wiele znaczących słów. W 1987 roku Milošević przemawiając do obywateli zgromadzonych na Kosowym Polu (obecnie na Gazimestanie) powiedział między innymi: „,(...) niech nikt Serba nie odważy się bić" ${ }^{53}$. Dość spektakularne było także odśpiewanie na cześć polityka pieśni upamiętniającej bitwę ze słowami: „Ty Lazarze, carze, byś żałował, że nie z Tobą Slobo spacerował" ${ }^{54}$.

Także Albańczycy z chęcią wykorzystują mity narodowe w konflikcie o Kosowo. Początków kultury albańskiej doszukiwano się już w czasach przedchrześcijańskich. Albańczycy twierdzą, że są potomkami Ilirów, którzy osiedlili się na terenach między Dunajem a Adriatykiem w II tysiącleciu przed naszą erą. Działania te były wsparte licznymi badaniami historycznymi, lingwistycznymi

${ }^{50}$ W. Korczyński, op. cit.

${ }^{51}$ Ibidem.

${ }^{52}$ J. Rapacka, Kult Vidovdanu, „Gazeta Wyborcza”, 1999, nr 79.

${ }^{53}$ N. Popov, Serbski dramat. Od faszystowskiego populizmu do Miloševicia, Warszawa 1994 s. 53, za: K. Kolaszko, Rola mitów narodowych w konflikcie kosowskim, www.prace_etnograficzne.republika.pl/7k.html.

${ }^{54}$ Ibidem, s. 132. 
czy też archeologicznymi. Często przytaczane informacje nie były zgodne z prawdą lub też częściowo odpowiadały stanowi faktycznemu. Oczywiście, nie miało to większego znaczenia. Historia, nawet nie do końca prawdziwa lub udokumentowana, miała za zadanie realizację interesu narodowego (w tym przypadku uzyskanie niepodległości). Odpowiednia manipulacja faktami ma spełnić swoje zadanie i przyczynić się do osiągnięcia ostatecznego celu. Ilirowie w pierwszych wiekach ulegli wpływom kulturowym Cesarstwa Rzymskiego, a po legalizacji chrześcijaństwa znaleźli się pod wpływami Wschodu i Zachodu ${ }^{55}$. Duży wpływ na percepcję ma również mit „Wielkiej Albanii”, który zakłada zjednoczenie wszystkich Albańczyków w jednym państwie. Jego geneza sięga początków XX wieku, kiedy Albańczycy zamieszkiwali cztery wilajety: Janina, Manastir, Kosowo, Shkodra.

\section{SPECYFIKA SPOŁECZNEJ KONSTRUKCJI NIEPODLEGŁOŚCI KOSOWA}

Trudno jednoznacznie ustalić, jaki jest status Kosowa. Środowisko międzynarodowe jest też w tej sprawie podzielone. Według Waltza na istotę państwa składa się pięć głównych cech. Pierwsza to porządek instytucjonalnoprawny (władza), druga to struktura społeczna lub organizacyjna, która ma monopol na zastosowanie siły, trzecia to suwerenność, czwarta to społeczeństwo. Ostatnią cechę stanowi terytorium. Wszystkie są ważne i niezbędne do prawidłowego funkcjonowania państwa. Władza związana jest z marksistowskim postrzeganiem państwa jako struktury; społeczne przyzwolenie na użycie siły i suwerenność to państwo jako aktor, natomiast wyeksponowanie społeczeństwa to pluralistyczny konstrukt ${ }^{56}$. Powołując się na Prawne kryteria państwowości przyjęte na mocy konwencji z Montevideo z roku 1933 (zgodnie z artykułem 1): „państwo jako podmiot prawa międzynarodowego powinno posiadać następujące elementy: (...) stałą ludność, suwerenną władzę, określone terytorium, zdolność wchodzenia w relacje międzynarodowe"57. Żeby zrozumieć, dlaczego Kosowo uważa się za państwo, należy się skoncentrować się na trzech podstawowych cechach wymienionych w konwencji i przywoływanych również przez konstruktywistów - władzy, terytorium, społeczeństwie.

Jako pierwszą należy poddać analizie władzę. W 1946 roku Kosowo otrzymało status regionu autonomicznego w obrębie Serbii. Od 1963 zostało uznane za prowincję autonomiczną. W 1976 roku, wraz z uchwalenie konstytu-

\footnotetext{
${ }^{55}$ J. Borkowicz, op. cit., s. 52.

${ }^{56}$ A. Wendt, Spoteczna..., s. 191.

${ }^{57}$ (Montevideo) Convention on Rights and Duties of States, 26.12.1933, http://www.internatrecht.unikiel.de/de/lehre/vorlesungen/archiv/ss2008/giegerich/vr2/materialien/PubIntLIIMontevid eo.pdf.
} 
cji Jugosławii, Kosowo otrzymało w pełni autonomiczny rząd ${ }^{58}$. Status ten utrzymał się do roku 1989, kiedy został odebrany przez nacjonalistę Slobodana Miloševića. Fakt ten był następstwem sytuacji w rejonie Kosowa. Albańczycy coraz chętniej i dobitniej artykułowali swoje prawa. Serbowie opowiadali się za zacieśnieniem współpracy $\mathrm{z}$ państwem macierzystym. Odebranie autonomii skutkowało wybuchem zamieszek, w których życie straciło ponad 20 osób. W 1990 roku do Kosowa zostało wysłane jugosłowiańskie wojsko i policja. W odpowiedzi zbuntowana prowincja proklamowała niepodległość, Serbia w ramach kontrdziałania rozwiązała parlament. Jako pierwsza niepodległość Kosowa uznała Albania. Od maja 1992 roku urząd prezydenta piastował Ibrahim Rugova ${ }^{59}$. Proporcje demograficzne między Albańczykami a Serbami były coraz bardziej niepokojące i pod koniec 1995 roku Albańczycy stanowili już $90 \%$ ogólnej liczby ludności w Kosowie ${ }^{60}$. Władze serbskie, chcąc doprowadzić do poprawy proporcji, zdecydowały się na przeprowadzenie działań mających na celu osiedlenie serbskich uchodźców z Chorwacji na terytorium Kosowa. Działanie przyniosło odwrotny efekt, przyczyniając się do zamieszek i protestów wśród kosowskich Albańczyków. Od 1996 roku działała Armia Wyzwolenia Kosowa (UÇK, alb. Ushtria Çlirimtare e Kosovës), której przypisywane są liczne porwania ludności serbskiej i romskiej ${ }^{61}$. Nadrzędnym celem tej paramilitarnej struktury było zjednoczenie ludności albańskiej zamieszkującej obszar Bałkanów (w tym głównie Albanię, Kosowo, Macedonię i Czarnogórę) i stworzenie tak zwanej „Wielkiej Albanii”. Ostatecznie skoncentrowano się na stworzeniu programu niepodległości Kosowa w wyniku secesji prowincji z pominięciem etapu przejściowego (stworzenia republiki w ramach Jugosławii) ${ }^{62}$.

Analiza działań UÇK potwierdza, że wielokrotnie ofiarami jej ataków była ludność cywilna. Teoretycznie operacje paramilitarne były wymierzone w serbskie siły policyjne i wojskowe, ale w praktyce dotykały także serbskich urzędników oraz Albańczyków podejrzewanych o kolaborację z Serbami. Oczywiście działania te były głęboko strategiczne i miały doprowadzić do zaognienia konfliktu, a w efekcie do wymuszenie interwencji zbrojnej ze strony państw zachodnich, na czele ze Stanami Zjednoczonymi. Human Rights Watch w raporcie z 2001 roku wykazała, że działania Armii Wyzwolenia Kosowa skierowane w ludność cywilną były elementem strategii militarnej. UÇK organizowało zasadzki w wioskach lub dokonywało krwawych ataków na jednostki poli-

58 W. Surówka, Kosowo - historia konfliktu, http://www.twojaeuropa.pl/1174/kosowohistoria-konfliktu.

${ }^{59}$ L. Kulińska, Konflikty $i$ punkty zapalne $w$ Europie, http://winntbg.bg.agh.edu.pl/skrypty2/0073/roz04.pdf.

${ }^{60}$ Ł. Raszczyński, Serbski problem demograficzny, http://www.twojaeuropa.pl/698/serbskiproblem-demograficzny.

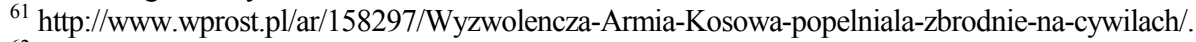

${ }^{62}$ M. Marcinko, Wyzwoleńcza Armia Kosowa: analiza struktury i ocena działalności, w: P. Czubik (red.), Bałkany u progu zjednoczonej Europy, Kraków 2008. 
cyjne i wojskowe, a następnie wycofywało się, narażając miejscową ludność na ataki odwetowe. Problem Kosowa miał być nagłośniony i stać się przedmiotem międzynarodowej dyskusji ${ }^{63}$. W 1997 roku Armia nasiliła ataki bombowe na serbskich cywilów i podejrzanych o zdradę Albańczyków. Do września przeprowadziła kilkanaście ataków na ludność cywilną i komisariaty, ostrzeliwała patrole policyjne i organizowała zasadzki. Punkt kulminacyjny nastąpił w roku 1998, kiedy doszło do walki między rebeliantami a policją w Drenicy. Wydarzenie to zapoczątkowało okres najbardziej krwawych wydarzeń o charakterze odwetowym $^{64}$. Coraz częstsze stały się ucieczki z obszarów zajętych walkami. Obie strony konfliktu starały się je wykorzystać do własnych celów. Mimo pogarszającej się sytuacji w regionie konfliktu, UÇK nie wyraziła zgody na negocjacje ze Slobodanem Miloševićem na temat przywrócenia autonomii, twierdząc, że punktem docelowym jej działań jest tylko suwerenność.

W roku 1998 sytuacja w Kosowie została podniesiona w rezolucji Organizacji Narodów Zjednoczonych. Rada Bezpieczeństwa wypowiedziała się na temat stosowania przemocy przez armię jugosłowiańską i serbskie siły wojskowe. Potępiono terroryzm jako środek osiągania celów o charakterze politycznym $^{65}$. Kilka dni później siły serbskie wycofały się do koszar. W miejscu konfliktu mieli pojawić się obserwatorzy OBWE, aby pilnować przestrzegania zasad pokoju. Nad regionem konfliktu miały przelatywać samoloty NATO ${ }^{66}$.

Uwzględniając ogrom ludzkiego cierpienia i bez względu na weto Rosji i Chin w Radzie Bezpieczeństwa ONZ, Rada zatwierdziła przymusowe działania, NATO rozpoczęło bombardowanie w marcu 1999 roku, a zakończyło w czerwcu. Siły serbskie zostały wypędzone i zastąpione przez KFOR ${ }^{67}$. Kosowo znalazło się pod nadzorem Organizacji Narodów Zjednoczonych. Rezolucja RB ONZ nr 1244 rozpoczęła długi proces budowania pokoju, stabilności, samorządności i demokracji ${ }^{68}$.

Teoretycznie można stwierdzić, że po 2008 roku Kosowo posiada określony ustrój instytucjonalno-prawny i władzę. Zgodnie z konstytucją z 2008 roku Kosowo jest republiką, na czele której stoi prezydent. Władzę ustawodawczą sprawuje 120-osobowe Zgromadzenie, w którym 20 miejsc zajmują mniejszości etniczne, w tym Serbowie. Egzekutywa należy do parlamentu. Problematyczna pozostaje niezależność (suwerenność) i skuteczność władzy ${ }^{69}$. Kwestia nieza-

${ }^{63}$ Human Right Watch, Uder Order: War Crimes in Kosowo,www.hrw.org/reports/2001/kosovo/undword.htm.

${ }^{64} \mathrm{http}: / / w w w . p o l i t y k a . p 1 /$ swiat/analizy/1507974,1,reportaz-kosowo-szuka-mitu.read.

${ }^{65} \mathrm{P}$. Sokołowska, Rola organizacji międzynarodowych po ogłoszeniu niepodległości Kosowa, s. 3 http://www.fpw.wroclaw.pl/pliki/P._Sokolowska,_Rola_organizacji_miedzynarodowych.pdf.

${ }^{66}$ Ibidem, s. 4.

${ }^{67} \mathrm{http}: / /$ www.msz.gov.pl/KFOR,(Kosovo,Force),29530.html.

${ }^{68}$ Ł. Kobeszko, ONZ-Kosowo rezolucja $n r 1244$ pozostaje $w$ mocy, http://www.psz.pl/index.php?option=content \&task=view\&id=10035.

${ }^{69} \mathrm{http}: / /$ encyklopedia.pwn.pl/haslo.php?id=4955057. 
leżności jest o tyle dyskusyjna, że Kosowo pozostaje pod mocnym wpływem głównego orędownika swojej niepodległości - USA. Aprobata USA była decydująca dla uzyskania niepodległości. Kosowo jako państwo jest pożądanym narzędziem realizacji interesów Stanów Zjednoczonych w regionie. Nowo utworzone państwo miało być cennym sojusznikiem w tak niestabilnym obszarze Europy, określanym już od wieków mianem „beczki prochu”70. Podczas wizyty w Kosowie wiceprezydent USA podkreślił, że (...) cała administracja Stanów Zjednoczonych jest zaangażowana w pomoc dla Kosowa" oraz stwierdził, że „(...) kosowska niepodległość jest nieodwołalna"71. Trudno też nie zauważyć, że USA jest głównym donatorem, który na pomoc nowo powstałemu państwu przekazał 1,1 mld dolarów ${ }^{72}$.

W tym miejscu pojawia się kolejna kwestia związana ze skutecznością władzy, a właściwie z samodzielnością w zaspokajaniu podstawowych potrzeb obywateli. Dobrobyt ekonomiczny zapewnia niezależność i jest wyznacznikiem sprawnie działającego państwa. Podczas Brukselskiej Międzynarodowej Konferencji Ofiarodawców, Bank Światowy, Międzynarodowy Fundusz Walutowy, USA i UE przyjęły plan rozwojowy dla Kosowa, na którego realizację zdecydowano się przekazać 1,2 mld euro. Pieniądze zostały przeznaczone na tak kluczowe i podstawowe rzeczy, jak budżet, spłata zadłużenia i tworzenie instytucji ${ }^{73}$.

Unia Europejska zdecydowała się na przekazanie 789 mln dolarów w ciągu czterech lat ${ }^{74}$. Tylko w roku 2008, czyli już w pierwszych miesiącach funkcjonowania państwa, Stany Zjednoczone zgodziły się na pomoc w wysokości $147 \mathrm{mln}$ dolarów, aż 24\% środków zostało wykorzystanych na tworzenie demokratycznych rządów ${ }^{75}$. Jak skomentował sytuację w Kosowie Stephen Krasner: „Ogłoszenie niepodległości przez Kosowo jest przykładem, że społeczność międzynarodowa może przyznać suwerenność małej, źle zarządzanej społeczności, otoczonej przez potencjalnie wrogo nastawionych sąsiadów" 76 .

Poza uzależnieniem od pomocy zewnętrznej, władza musi poradzić sobie z ogromnymi problemami wewnętrznymi. Państwo zmaga się z korupcją i wpływami mafii. Powiązania ze światem przestępczym obejmują najwyższych przedstawicieli administracji państwowej. Sam premier Thaci został postawiony w stan oskarżenia za handel bronią i ludzkimi organami. Za malwersacje finansowe

\footnotetext{
${ }^{70} \mathrm{http} / /$ www.doss.wroclaw.pl/index.php?option=com content\&view=article\&id=118:kosowodzi-ocena-sytuacji-najmodszego-pastwa-europy\&catid=40: analizy\&Itemid=59.

${ }^{71}$ K. Dirote, Kosowo wita przyjaciela, ,Rzeczpospolita”, 2009, $\mathrm{nr} 5$.

72 S. Kaufman, United States Pledges $\$ 400$ Million at Kosovo Donors' Conference, www.america.gov.

${ }^{73} \mathrm{http}: / /$ www.reuters.com/article/2008/07/10/idUS212583+10-Jul-2008+PRN20080710.

${ }^{74}$ Ibidem.

${ }^{75}$ P. Sierpień, Działania USA w Kosowie, http://www.psz.pl/tekst-24756/Przemyslaw-SierpienDzialaniaUSA-w-Kosowie.

${ }^{76}$ S. Krasner, Who Gets a State, and Why?, http://www.foreignaffairs.com/artic-les/64872/stephen-dkrasner/who-gets-a-state-and-why.
} 
aresztowano urzędników Ministerstwa Zdrowia ${ }^{77}$. Jeśli zatem przedstawione fakty zestawimy z definicją suwerenności zaproponowaną przez Ludwika Ehrlicha: „suwerenność oznacza samowładność, czyli prawną niezależność od jakichkolwiek czynników zewnętrznych i całowładność, czyli kompetencję normowania wszystkich stosunków wewnątrz państwa", trudno określić Kosowo mianem suwerennego podmiotu ${ }^{78}$.

Drugą bezwzględną cechą konieczną do stworzenia państwa jest terytorium. Kosowo zajmuje obszar $10,9 \%$ tys. $\mathrm{km} \mathrm{kw}^{79}$. W czasach średniowiecza uważane było za serbski heartland. Kluczowym momentem była walka na Kosowym Polu, gdzie Serbowie razem z Albańczykami walczyli przeciwko tureckiej dominacji. Od 1389 roku terytorium Kosowa znajdowało się pod turecką dominacją. W 1912 roku ponownie powróciło do Serbii ${ }^{80}$. Kosowo uzyskało status autonomiczny pod rządami marszałka Tito ${ }^{81}$. W 1999 roku na to terytorium wkroczyły siły międzynarodowe NATO.

Jak widać, terytorium na przestrzeni wieków znajdowało się pod panowaniem różnych państw i narodów. Istnieją trzy główne teorie definiowania przynależności terytorium do narodu, które mają odniesienie do regionu Bałkanów.

Pierwsze odnosi się do prawa narodów połączonych wspólną tożsamością do ziem historycznie z nimi związanych. Zgodnie z jej założeniami zarówno Serbowie, jak i Albańczycy mają prawo do kosowskiej ziemi.

Drugie odnosi się do państw demokratycznych, w których narody mają prawo do określania swojego związku z terytorium poprzez referendum. Zasada wypracowana przez Organizację Narodów Zjednoczonych zakłada poszanowanie wszystkich granic państwowych, wpisując ich istnienie w zasadę integralności. Zgodnie z tymi założeniami państwa są nietykalne, a każde użycie siły fizycznej, mające na celu zmianę granic, jest bezprawne.

Zasada uti possidentis juris, która znalazła zastosowanie w Ameryce Łacińskiej podczas rozstrzygania kwestii granicznych byłych kolonii, nie miałaby zastosowania w przypadku Kosowa ${ }^{82}$. Ze względu na ogromną dysproporcję demograficzną generowałaby kolejne spory. Lepszym rozwiązaniem wydaje się przyjęcie zasady possidetis de facto ${ }^{83}$. Terytorium należy do podmiotu, który sprawuje władzę. Kosowo jest poza obszarem władzy Serbii, co oznacza, że

\footnotetext{
${ }^{77}$ P. Kościński, Premier Thaci oskarżony, http://www.rp.pl/artykul/579026.html.

${ }^{78}$ L. Ehrlich, Prawo narodów, Kraków 1947, s. 104.

${ }^{79} \mathrm{http} / / /$ wiadomosci.gazeta.pl/wiadomosci/1,114873,4936485.html.

${ }^{80}$ R.A. Smentek, Kosowo - historycznie, http://www.wiadomosci24.pl/artykul/kosowo_historycznie 59095.html.

81 M. Staniul, Prawdziwa historia wolnego Kosowa, http://www.stosunkimiedzynarodowe.pl/prawdziwa-historia-wolnego-kosowa.

${ }^{82}$ Uti possidentis zakłada, że strony konfliktu decydują się na zakończenie konfliktu, godząc się na aktualne straty i korzyści terytorialne.

${ }^{83}$ K.R. Sejdiu, The Revival of a Forgotten Dispute: Deciding Kosova's Future, „Rutgers University Journal of Law and Urban Policy", 2005, nr 3, s. 11.
} 
w myśl possidentis de facto nie może do niej należeć ${ }^{84}$. System ONZ zakłada, że jednostki terytorialne, które nie uzyskały niepodległości, mogą odwoływać się do zasady samostanowienia $\mathrm{w}$ celu uzyskania suwerenności ${ }^{85}$. Teoretycznie podział Jugosławii miał odbywać się według wspomnianej zasady. W przeciwieństwie do dekolonizacji, zakładał uwzględnienie różnorodności etnicznej, językowej i kulturowej. Sprawa Kosowa udowodniła, że samostanowienie może być wykorzystywane przez grupy narodowo-etniczne do realizacji swoich indywidualnych praw (w tym praw człowieka). Nie oznacza to, że dana grupa etniczna musi od razu utworzyć państwo, które zapewni respektowanie praw. Wystarczy, że prawa mogą być wypełnione w ramach autonomii (jak utrzymują Serbowie) ${ }^{86}$.

Ostatnim z trzech czynników jest społeczeństwo. Kosowo jest zamieszkiwane głównie przez Albańczyków. Mniejszość etniczną na tym obszarze stanowią między innymi Serbowie ${ }^{87}$. Jeszcze na początku XX w. Albańczycy stanowili $70 \%$ populacji, obecnie ponad $90 \%$. Główną przyczyną tego stanu rzeczy jest wzrost demograficzny. Współczynnik dzietności dla tego narodu jest jednym z najwyższych na świecie. Na statystyczną kobietę przypada prawie ośmioro dzieci ${ }^{88}$. Główną cechą odróżniającą Albańczyków od Serbów jest religia. O ile Albańczycy to muzułmanie, o tyle Serbowie to w większości ludność prawosławna $^{89}$. Różnice kulturowe, religijne i historyczne były przyczyną licznych konfliktów. Czystki etniczne stosowane przez serbski rząd zaostrzyły sytuację wewnętrzną, dostarczając Albańczykom pretekstu do walki o niepodległość prowincji. Wzajemne prześladowania doprowadziły tylko do wzmocnienia tożsamości i przyczyniły się do rozrostu narodowej mitologii. Co istotne, zdecydowany wpływ na ostateczny kształt tożsamości miało tworzenie jej w oparciu o poczucie odmienności od sąsiada ${ }^{90}$.

Obecnie w świecie stosunków międzynarodowych dominuje pogląd, że suwerenny podmiot jest $\mathrm{w}$ stanie zapewnić wyższy stopień bezpieczeństwa niż aktor niepaństwowy. Państwa są w stanie zapewnić lepszą ochronę i warunki rozwoju, a przede wszystkim są bardziej przewidywalne. Czystki etniczne dokonane przez rząd serbski w 1990 roku udowodniły, że państwo nie zapewnia całkowitego bezpieczeństwa swoim obywatelom, a podjęte działania dają od-

${ }^{84}$ T. Srogosz, Charakter prawny uti possidetis $w$ prawie międzynarodowym, „Państwo i Prawo", 2011, nr 6, http://www.grocjusz.edu.p1/Materials/js_23.03.2012.pdf.

${ }^{85}$ K. S. Shehadi, Clash of Principles: Self-determination, State Sovereignty, and Ethnic Conflict, w: S.H. Hashmi (ed.), State sovernginity. Chance and persistance in international relation, Pennsylvania 1997, s. 131.

${ }^{86}$ Ibidem, s. 144

${ }^{87}$ R.A. Smentek, Kosowo historycznie, http://www.wiadomości24.pl/artykul/kosowo_historycznie 59095.html.

${ }^{88}$ D. Ćesić, Kosowo jest serbskie, http://www.wprost.pl/ar/123911/Kosowo-jest-serbskie/.

${ }^{89}$ Ibidem.

${ }^{90}$ H. Hannum, Autonomy, Sovereignty, and Self-Determination: The Accommodation of Conflicting Rights, Philadelphia 1990, s. 6. 
wrotny skutek. Wydarzeniami w Kosowie interesuje się opinia publiczna na całym świecie, a Albańczycy coraz bardziej wierzą, że uda im się utworzyć niepodległe państwo. Zgodnie z założeniami Organizacji Narodów Zjednoczonych i Planu Realizacji Standardów w Kosowie każdy mieszkaniec powinien uczestniczyć w życiu politycznym, społecznym i gospodarczym, angażować się w życie polityczne i społeczne bez względu na pochodzenie etniczne.

Podsumowując, suwerenność jest normą o pochodzeniu społecznym. Ewolucja pojęcia spowodowała, że często pojawia się problem definicyjny. Dyskusyjny pozostaje też fakt, czy interwencja humanitarna stanowi zagrożenie dla suwerenności i może być usprawiedliwiana. Trudno jest pogodzić zasadę integralności terytorialnej z prawem do samostanowienia narodów. Analizując sytuację w Kosowie można stwierdzić, że w hierarchii priorytetów Serbii znajduje się zachowanie całości terytorium, natomiast dla Albańczyków najważniejsze jest stworzenie warunków do rozwoju we własnym państwie. Chociaż Kosowo teoretycznie posiada wszystkie atrybuty państwa, to wciąż dyskusyjna pozostaje ocena jego suwerenności. Uzależnione od pomocy międzynarodowej, zmagające się z ogromnym bezrobociem i korupcją na najwyższych szczeblach władzy nie jest w stanie samodzielnie i efektywnie realizować funkcji przypisanych państwu.

Znaczenie konfliktu o Kosowo jest pochodną subiektywnej (Albańczycy, Serbowie) i intersubiektywnej (podmioty środowiska międzynarodowego) wizji sytuacji na Bałkanach, odbieranej przez pryzmat interesów państw. Suwerenność, podobnie jak tożsamość, jest społecznym konstruktorem, zatem jej istnienie jest związane z percepcją podmiotów struktury. Ponieważ odbiór rzeczywistości przez poszczególnych uczestników jest różny, trudno znaleźć rozwiązanie satysfakcjonujące wszystkich. W przypadku Kosowa suwerenność jest związana z przekonaniem (zarówno społeczeństwa, jak i elit politycznych) o niezależności od Serbii i tworzeniu samodzielnego bytu. Niewątpliwie w konstruowaniu suwerenności pomaga poparcie USA i UE, znaczące różnice kulturowe, oraz przewaga demograficzna Albańczyków. Dzięki temu proces tworzenia suwerenności przebiegał bardzo szybko na poziomie świadomościowym, a dopiero później znalazł (przynajmniej prowizorycznie) odbicie w stanie formalno-prawnym.

\section{THE SOCIAL CONSTRUCTION OF KOSOVO'S INDEPENDENCE}

Summary. This article analyzes the sovereignty of Kosovo, using social theory of international relation. It presents the evolution of the definition of sovereignty as well as conflicts between the principle of self-determination and territorial integrity of Kosovo, as an example. Immaterial factors (mainly national identity) affects the formation of national interest, including the establishment of an independent state. Culture, history and national myths are essential for creating behavior on both sides of the conflict. This article presents the main determinants of Kosovo's sovereignty - territory, population, authority.

Key words: Serbia, Kosovo, Albania, independence, social theory of international relations 